\title{
Increasing Labor Efficiency Repairing Metal Structures of Heavy-Duty Quarry Machinery
}

\author{
Michael Drygin ${ }^{1, *}$, and Nikolai Kuryshkin ${ }^{1}$ \\ ${ }^{1}$ T.F. Gorbachev Kuzbass State Technical University, Department of Information and Automated \\ Manufacturing Systems, 650000 Kemerovo, Russian Federation
}

\begin{abstract}
Supporting metal structures of large dump trucks at open cast coal mines function under exposure to alternating cyclic load. Fatigue cracks that appear there require timely maintenance welding. Organization of repair processes is multivariant; it can be performed either by the enterprise (open cast coal mine) efforts or by special repair units. An industrial experiment carried out at Permyakovskiy and Prokopyevskiy open cast coal mines in Kuzbass has shown that type of large dump trucks' repair works organization influences significantly process efficiency. Repair welding by enterprise efforts is the most non-productive compared to other types of repair process organization. Its specific rate is 37 per cent lower than in comparison with unstructured welding and 2.2 times lower in comparison with structured metal sheet replacement and structured welding. Structuring repair processes allows to increase their efficiency by $30 \ldots 40$ per cent on average. Structured replacement of the spring plate is the most productive type of metal structure repair process organization. Comparison of maintenance measurement results in accordance with Unified Norms and Prices collected book with the results obtained from the industrial experiment showed that calculation methods give underestimated values of repair processes' specific rate.
\end{abstract}

\section{Introduction}

Since open cast coal mining has obviously more advantages in comparison with underground mining, more than 70 per cent of all Russian coal is mined by quarrying. Kuznetsk basin (Kuzbass) is one of the largest in Russia and in the world [1-5]. Meanwhile within the period of last twenty-five years investments in coal mining industry were insignificant. Even in the most stable year, 2010, they were equal to 5 per cent from coal sales revenue [6].

Within this unfavorable investment environment open cast coal mines are still using technological machines with expired statutory service life. As a result, 70 per cent of equipment undergoes industrial safety expert review, and technical state of more than $86 \%$ per cent of equipment is inappropriate [7].

Technological machines function within long periods of time with their main structural metal sections (frames of large dump trucks, booms of power shovels, etc.) exposed to

\footnotetext{
* Corresponding author: mike.drygin@gmail.com
} 
heavy cyclic load. This leads to formation and propagation of fatigue cracks, and eventually to fracturing of the metallic structures. Timely detection of cracks and further repair of structural metallic sections allows to increase significantly the lifespan of technological equipment and save financial resource for buying new machinery $[8,9]$.

\section{Formulation of the Problem}

The technology of metallic structures' repair is multioperational, multivariant and rather labor-consuming. Its optimization in terms of cost criteria and maintaining the required quality is a current task, and the solution for this task will give the enterprise a significant economic effect.

Multivariance of repair works on metallic structures means that they can be carried out either by enterprise efforts (an open cast coal mine) or by special repair units. On top of this, in the first case repair works are organized by the enterprise's superiors. In the second case the foreman (overseer) can combine duties of an engineering staff worker with a service job. This type of repair will be further called unstructured. If the foreman (overseer) performs his duties (organization and control of the permit-to-work system, etc.), and each worker in the repair crew performs his work (welder, backgouger, repairman), this type of repair is called structured.

Repair can be also subdivided into two types:

- when repair means welding of weak seams on gouged out cracks, this type is called "welding";

- when on top of welding of weak seams it is necessary to replace a defective part, this type is called "metal sheet replacement".

Therefore it is a system of three types of works and two types of repair which give the following variants when combined: unstructured welding; structured welding; structured replacement of a metal sheet; unstructured replacement of a metal sheet; welding by enterprise efforts.

A theoretical model with the same basic benchmark data (length and number of seams, materials, etc.), but with labor intensity calculated in accordance with Unified Norms and Prices, will be added to each repair performed at an enterprise $[9,10]$.

Therefore, two more variants of repair are added to the previous five: estimated welding and estimated replacement of a metal sheet.

Controlled repair works, stopwatch study and data processing were carried out at thirteen objects of open cast coal mines Permyakovskiy and Prokopyevskiy. Each worker was given a clock number which was then registered near each welding seam. After repair works full quality check of the welding seams was performed. Metallic structure of large dump trucks BelAZ 75131 and BelAZ 7555 were repaired. During the works more than 1 200 welding seams were repaired, 6,5 tons metal sheets were replaced. The overall length of the seams was more than $475 \mathrm{~m}$. Average length of repair seams was $400 \mathrm{~mm} .20$ welders, 27 repairmen, and 23 backgougers from the third to the sixth skill category with different working skills and experience were involved in the repair works.

\section{Theoretic}

\subsection{Benchmark Data for Calculations and Analysis}

Benchmark data for calculation and analysis include: general labor intensity of the works; work time for each person involved; lengths of welding seams; average thickness of the welding seams. Primary benchmark data are presented in Table 1. 
Table 1. Primary Benchmark Data.

\begin{tabular}{|c|c|c|l|c|c|c|c|}
\hline $\begin{array}{c}\text { Truck make, } \\
\text { model }\end{array}$ & $\begin{array}{c}\text { Truck } \\
\text { Identification } \\
\text { Number }\end{array}$ & $\begin{array}{c}\text { Repair } \\
\text { object }\end{array}$ & Repair type & $\begin{array}{c}\text { Welding } \\
\text { seam } \\
\text { length/mm }\end{array}$ & $\begin{array}{c}\text { Labor } \\
\text { intensity } \\
\text { /hr. }\end{array}$ & $\begin{array}{c}\text { Welding } \\
\text { seam } \\
\text { thickness/mm }\end{array}$ & $\begin{array}{c}\text { Number } \\
\text { of } \\
\text { junction } \\
\text { /items }\end{array}$ \\
\hline BelAZ 75131 & 1697 & $\begin{array}{c}\text { overhung } \\
\text { support }\end{array}$ & $\begin{array}{l}\text { unstructured } \\
\text { welding }\end{array}$ & 650 & 31 & 20.68 & 3 \\
\hline BelAZ 75131 & 1014 & $\begin{array}{c}\text { dumping } \\
\text { body }\end{array}$ & $\begin{array}{l}\text { unstructured } \\
\text { welding }\end{array}$ & 12000 & 269 & 10.15 & 25 \\
\hline BelAZ 75131 & 1604 & frame & $\begin{array}{l}\text { unstructured } \\
\text { welding }\end{array}$ & 36405 & 1134 & 19.78 & 74 \\
\hline BelAZ 7555 & 1454 & frame & $\begin{array}{l}\text { unstructured } \\
\text { welding }\end{array}$ & 10140 & 222 & 13.5 & 24 \\
\hline BelAZ 75131 & 1716 & frame & $\begin{array}{l}\text { unstructured } \\
\text { replacement }\end{array}$ & 15960 & 270 & 18.7 & 33 \\
\hline BelAZ 75131 & 1595 & frame & $\begin{array}{l}\text { unstructured } \\
\text { welding }\end{array}$ & 9630 & 306 & 20.67 & 23 \\
\hline BelAZ 7555 & 1744 & frame & $\begin{array}{l}\text { structured } \\
\text { replacement }\end{array}$ & 33336 & 540 & 15.08 & 84 \\
\hline BelAZ 75131 & 1009 & frame & $\begin{array}{l}\text { structured } \\
\text { welding }\end{array}$ & 54300 & 1238 & 20.61 & 160 \\
\hline BelAZ 75131 & 1014 & frame & $\begin{array}{l}\text { structured } \\
\text { replacement }\end{array}$ & 73965 & 1314 & 21.0 & 177 \\
\hline BelAZ 7555 & 233 & frame & $\begin{array}{l}\text { unstructured } \\
\text { replacement }\end{array}$ & 65405 & 1704 & 15.0 & 119 \\
\hline BelAZ 7555 & 253 & frame & $\begin{array}{l}\text { structured } \\
\text { replacement }\end{array}$ & 42390 & 720 & 15.0 & 91 \\
\hline BelAZ 7555 & - & $\begin{array}{l}\text { frame } \\
\text { enterprise } \\
\text { efforts }\end{array}$ & 25625 & 816 & 13.5 & 100 \\
\hline BelAZ 7555 & 208 & $\begin{array}{l}\text { enterprise } \\
\text { efforts }\end{array}$ & 35210 & 1392 & 19.6 & 95 \\
\hline
\end{tabular}

Primary benchmark data include the data on the expendables. These data and the auxiliary data on welding seams section calculated in accordance with Table 1 are presented in Table 2 .

Table 2. Auxiliary Data on Expendables.

\begin{tabular}{|l|c|c|c|c|c|c|}
\hline $\begin{array}{c}\text { Truck make, } \\
\text { model }\end{array}$ & $\begin{array}{c}\text { Truck } \\
\text { Identification } \\
\text { Number }\end{array}$ & $\begin{array}{c}\text { Carbon } \\
\text { electrode } \\
\text { per item }\end{array}$ & $\begin{array}{c}\text { Abrasive } \\
\text { wheel D125 } \\
\text { per item }\end{array}$ & $\begin{array}{c}\text { Abrasive } \\
\text { wheel D230 } \\
\text { per item }\end{array}$ & $\begin{array}{c}\text { Specific } \\
\text { wireline } \\
\text { discharge } \\
/ \mathrm{kg} / \mathrm{m}\end{array}$ & $\begin{array}{c}\text { Welding } \\
\text { seam section } \\
/ \mathrm{mm}^{2}\end{array}$ \\
\hline BelAZ 75131 & 1697 & 10 & 1 & - & 7.69 & 977.42 \\
\hline BelAZ 75131 & 1014 & 47 & 5 & 5 & 2.25 & 285.90 \\
\hline BelAZ 75131 & 1604 & 235 & 20 & 30 & 5.93 & 753.91 \\
\hline BelAZ 7555 & 1454 & 38 & 8 & - & 3.35 & 426.06 \\
\hline BelAZ 75131 & 1716 & 68 & 7 & 4 & 4.20 & 533.42 \\
\hline BelAZ 75131 & 1595 & 107 & 6 & 5 & 5.19 & 659.73 \\
\hline BelAZ 7555 & 1744 & 240 & 8 & 20 & 4.95 & 628.92 \\
\hline BelAZ 75131 & 1009 & 551 & 34 & 23 & 5.22 & 663.17 \\
\hline
\end{tabular}




\begin{tabular}{|l|c|c|c|c|c|c|}
\hline BelAZ 75131 & 1014 & 365 & 42 & 45 & 4.19 & 532.6 \\
\hline BelAZ 7555 & 233 & 350 & 28 & 36 & 2.94 & 373.0 \\
\hline BelAZ 7555 & 253 & 250 & 19 & 24 & 3.02 & 383.7 \\
\hline BelAZ 7555 & - & 150 & 25 & - & 3.51 & 446.3 \\
\hline BelAZ 7555 & 208 & 140 & 15 & 9 & 3.98 & 505.2 \\
\hline
\end{tabular}

\subsection{Calculating Theoretical Labor Intensity in Accordance with Unified Norms and Prices}

The key factor of applying Unified Norms and Prices for calculation labor intensity for repair of BelAZ mine dump trucks' metal structures is the highest proximity of quality demands for pipeline welding, stated norms for welding joints and related works in different positions with similar complexity factors and length of singular joints. The main differences in this case are: a complicating factor of welding joints' curvature and deviation of the welding joint width form the National State Standard parameters (applied in Unified Norms and Prices collected book).

The process of repair welding presupposes removing the crack of the previously performed welding joint identified in the National State Standard, removing the weldaffected zone and forming acceptable groove allowing fulfilling requirements of full penetration welding. As a rule, cracks in welding seams of metallic structures to repair form in weld-affected zones of welding joints (Figure 1).

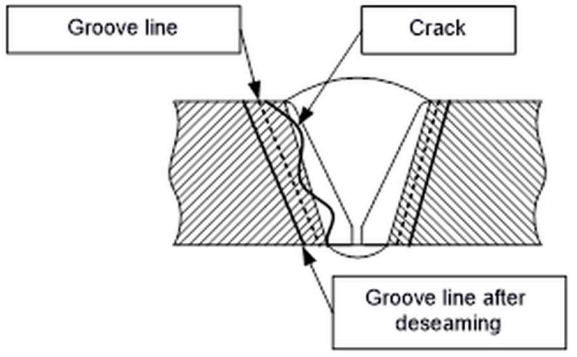

Fig. 1. Repair Weld Groove.

The main purpose of the crack dressing out is removing the metal of the welding seam, its weld-affected zone, the crack, and the metal exposed to fatigue fracture in the area close to the defective zone. The obtained groove is shown in Figure 1 as a dotted line.

Edge dressing with an angle grinder to a depth of $2 \ldots 3 \mathrm{~mm}$ is performed in order to remove the carburized layer of the basic metal. The result of the final groove is shown in Figure 1 as a solid line. The result of the performed works is preliminary groove with technology-based double or triple excess of welding seam cross-section according to the National State Standard. However, during next repair works the width of the seam will extend in multiplies of the performed works' number.

Using primary data of Table 1 and Table 2 and welding seam groove scheme (Figure 1), time for certain operations was calculated in accordance with the procedures stated in the Unified Norms and Prices. Calculations were performed for each metallic structure of all mine dump trucks. Overall time of repair works was determined by summing up the time taken by singular operations: groove, edge dressing, heating, tack-welding, welding, annealing, dressing of the weld-affected zone before ultrasonic test (UT). Calculation results are presented in Table 3 . 
Table 3. Estimated Labor Intensity of Repair Works, w.h.

\begin{tabular}{|l|c|c|c|c|c|c|c|c|c|}
\hline $\begin{array}{l}\text { Truck } \\
\text { make, } \\
\text { model }\end{array}$ & $\begin{array}{c}\text { Truck } \\
\text { Identificatio } \\
\text { n Number }\end{array}$ & Groove & $\begin{array}{c}\text { Edge } \\
\text { dressing }\end{array}$ & Heating & $\begin{array}{c}\text { Tack- } \\
\text { welding }\end{array}$ & Welding & Annealing & $\begin{array}{c}\text { Weld- } \\
\text { affected } \\
\text { zone } \\
\text { dressing } \\
\text { before } \\
\text { UT }\end{array}$ & $\begin{array}{c}\text { General } \\
\text { labor } \\
\text { intensity }\end{array}$ \\
\hline $\begin{array}{l}\text { BelAZ } \\
75131\end{array}$ & 1697 & 0.76 & 2.07 & 0.81 & 0.18 & 27.96 & 0.81 & 3.3 & 37.8 \\
\hline $\begin{array}{l}\text { BelAZ } \\
75131\end{array}$ & 1014 & 7.91 & 22.72 & 9.75 & 2.25 & 182.51 & 9.75 & 38.75 & 295.9 \\
\hline $\begin{array}{l}\text { BelAZ } \\
75131\end{array}$ & 1604 & 28.08 & 101.67 & 60.68 & 6.66 & 1054.25 & 60.68 & 114.7 & 1510.3 \\
\hline $\begin{array}{l}\text { BelAZ } \\
7555\end{array}$ & 1454 & 9.11 & 19.80 & 9.36 & 2.16 & 215.07 & 9.36 & 37.2 & 319.1 \\
\hline $\begin{array}{l}\text { BelAZ } \\
75131\end{array}$ & 1716 & 12.52 & 43.62 & 27.06 & 2.97 & 297.63 & 27.06 & 51.15 & 491.7 \\
\hline $\begin{array}{l}\text { BelAZ } \\
75131\end{array}$ & 1595 & 8.73 & 24.38 & 18.86 & 2.07 & 210.48 & 18.86 & 41.4 & 341.2 \\
\hline $\begin{array}{l}\text { BelAZ } \\
7555\end{array}$ & 1744 & 31.88 & 73.64 & 68.88 & 7.56 & 978.84 & 68.88 & 130.2 & 1433.3 \\
\hline $\begin{array}{l}\text { BelAZ } \\
75131\end{array}$ & 1009 & 50.60 & 169.26 & 62.4 & 14.4 & 1379.88 & 62.4 & 176 & 2029.9 \\
\hline $\begin{array}{l}\text { BelAZ } \\
75131\end{array}$ & 1014 & 67.17 & 189.51 & 145.14 & 15.93 & 1307.5 & 145.14 & 318.6 & 2296.4 \\
\hline $\begin{array}{l}\text { BelAZ } \\
7555\end{array}$ & 233 & 52.69 & 136.03 & 174.93 & 10.71 & 1075.5 & 174.93 & 243.95 & 1965.1 \\
\hline $\begin{array}{l}\text { BelAZ } \\
7555\end{array}$ & 253 & 34.53 & 79.53 & 74.62 & 8.19 & 696.7 & 74.62 & 141.05 & 1164.8 \\
\hline $\begin{array}{l}\text { BelAZ } \\
7555\end{array}$ & - & 28.46 & 54.17 & 39 & 6 & 766.6 & 39 & 95 & 1075.5 \\
\hline $\begin{array}{l}\text { BelAZ } \\
7555\end{array}$ & 208 & 36.05 & 97.35 & 77.9 & 8.55 & 763.8 & 77.9 & 147.25 & 1267.1 \\
\hline
\end{tabular}

\subsection{Calculation of Repair Works' Specific Rate}

Specific rate determines repair productivity. Specific rate of welding as the basic operation is calculated according to the following formula:

$$
v_{v e l}=S L / T_{v e l},
$$

where $S$ is welding seam section, $\mathrm{mm}^{2} ; L$ is welding seam length, мм; $T_{v e l}$ is labor intensity of welding, w.h.

Specific rate of the workers of other professions is calculated using the following formula:

$$
v_{\text {prof }}=v_{\text {vel }} T_{\text {prof }} / T_{\Sigma},
$$

where $T_{\text {prof }}$ is labor intensity of operations performed by a worker of one profession, w. h.; $T_{\Sigma}$ is general labor intensity of repair, w.h.

The same formulae were applied for calculation of estimated specific rate according to Unified Norms and Prices. 


\section{Results and Analysis}

The results of specific rate calculation for different professions are shown in a diagram in Figure 2. This diagram shows that specific rate for different professions varies from 1262 $\mathrm{mm}^{3} /$ w.h. to $10940 \mathrm{~mm}^{3} / \mathrm{w} . \mathrm{h}$. At the same time the overall specific rate is within the range from $6698 \mathrm{~mm}^{3} / \mathrm{w} . \mathrm{h}$. to $30464 \mathrm{~mm}^{3} / \mathrm{w} . \mathrm{h}$.

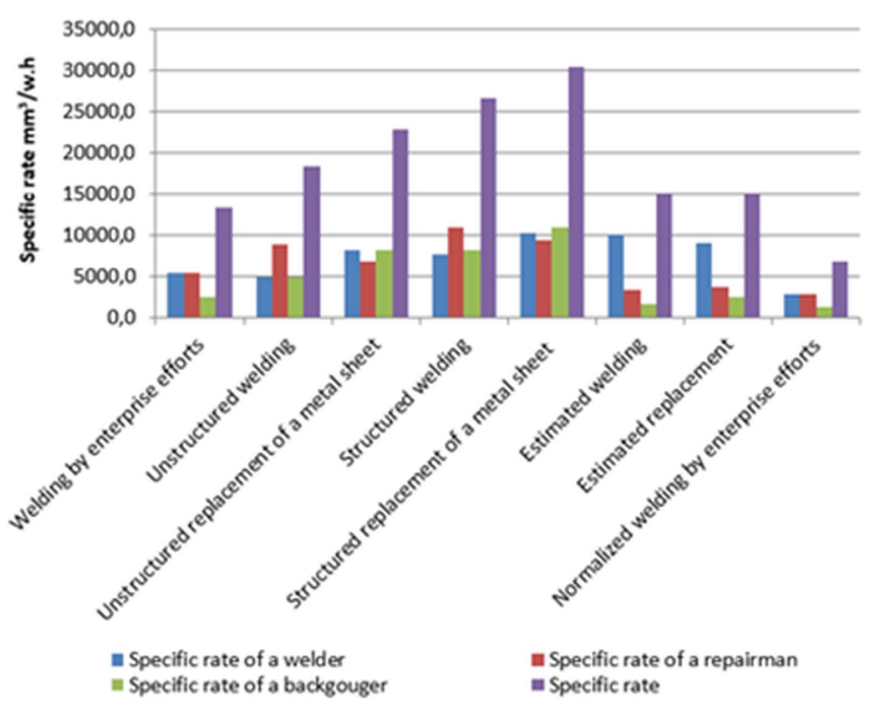

Fig. 2. Repair Works Specific Rate by Professions and Organizational Structure.

The diagram also shows that the lowest specific rate of repair works was observed when they were performed by enterprise efforts. Moreover, this rate was twice lower than maximum shown during structured replacement of metal sheet. With any organizational form of the repair works (structured or unstructured), replacement of the metal sheet was more productive (by 15 20 per cent) than welding repair seams. Structured repair works are more productive than unstructured (by $25 \sim 30 \%$ per cent).

Estimated specific rate of repair works (according to Unified Norms and Prices) proved to be much lower than real one. At the same time, it proved to be similar for repair seam welding and for replacement of the metal sheet for all professions.

Summarizing specific rates of repair works by their organizational type for all professions and finding maximum and minimum specific rate, we will have the diagram presented in 3 .

Main trends shown in Figure 2 remained in Figure 3. Significant variation of minimum and maximum specific rates of metal sheets replacement, both structured and unstructured, is obvious. Specific rate of welding by enterprise efforts is twice lower than of structured welding. Specific rate of structured welding is by 40 per cent more than of unstructured welding. Structured metal sheet replacement is more productive than unstructured replacement by 30 per cent. 


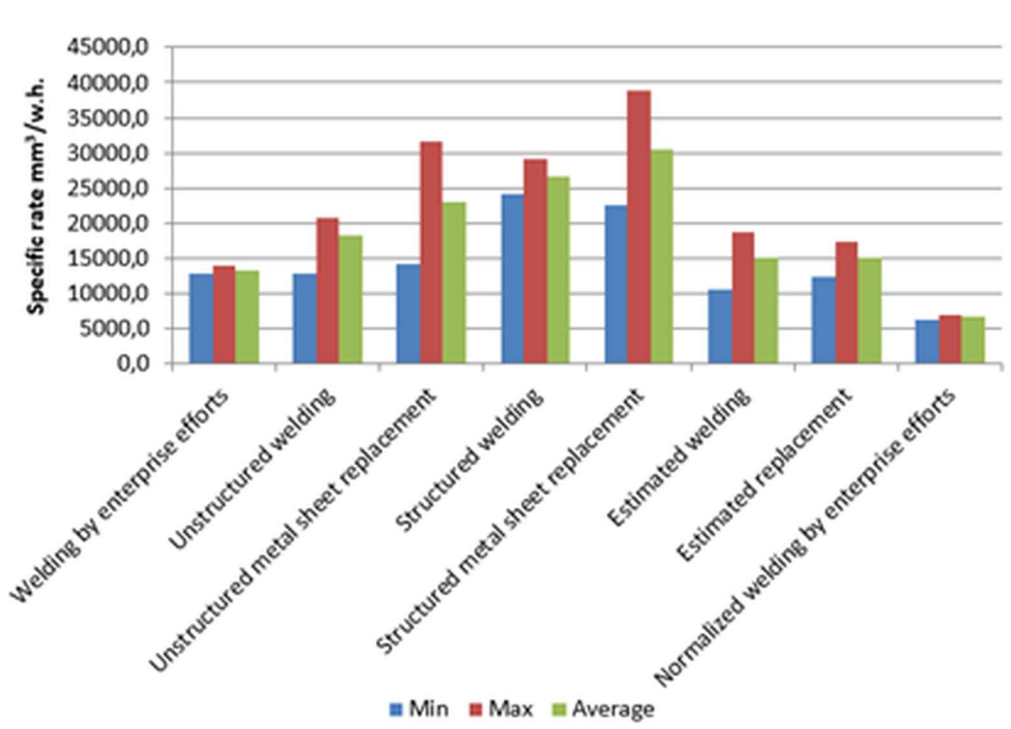

Fig. 3. General Specific Rate by the Type of Repair Works Organization.

\section{Conclusion}

1. Form of large mine dump trucks' repair works organization influences significantly productivity of the process. Specific rate of the repair works varies from $6698 \mathrm{~mm} 3 / \mathrm{w} . \mathrm{h}$. to $30464 \mathrm{~mm} 3 / \mathrm{w} . h$. due to the form of works organization.

2. The industrial experiment has shown that repair welding by enterprise efforts is the most non-productive in comparison with other types of repair work organization. Its specific rate is lower by 37 per cent than unstructured welding and 2.2 times lower than structured replacement of the metal sheet.

3. The most productive types of metallic structures' repair organization are structured replacement of the metal sheet and structured welding. Structuring of repair processes allows to increase their productivity on an average by $30 \ldots 40$ per cent.

4. The most productive type of metallic structures' repair work organization is structured replacement of a metal sheet. Its specific rate is higher than that of structured welding by 15 per cent.

5. Comparison of repair work standardization results in accordance with Unified Norms and Prices with the results of the industrial experiment shows that estimated methods give reduced values of repair processes' specific rate. Therefore, current Unified Norms and Prices worked out more than thirty years ago are out of date and need to be revised.

\section{References}

1. H. Arden, A. Tverdov, Mineral Resource and Ore Reserve Estimation. The AusIMM Guide to Good Practice (DTMGF, Berlin, 2014)

2. V. Kovalev, A. Khoreshok, O. Litvin, The 8th Russian-Chinese symposium coal in the 21st century: mining, processing and safety, 287, 1 (2016)

3. A. Morshedlou, H. Dehghani, S. H. Hoseinie, JME, 5, 2 (2014)

4. M. Drygin, N. Kurychkin, A. Bakanov, E3S Web Conf. 15, 03011 (2017) 
5. M. Drygin, N. Kuryshkin, JOP: Conf. Series. 944, 012029 (2018)

6. E. Todorov, R. Spencer and M. Lozev, M. E., 72, 6 (2014)

7. L. De Chiffre, S. Carmignato, R. Kruth, J. P. Schmitt, A. Weckenmann, Manuf. Technol., 63, 2 (2014) 